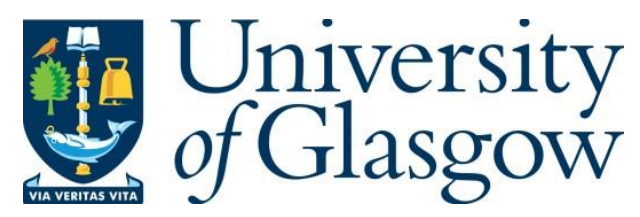

Kuenzler, S. (2019) Sites of memory in the Irish landscape? Approaching ogham stones through memory studies. Memory Studies (doi:10.1177/1750698018818226)

There may be differences between this version and the published version. You are advised to consult the publisher's version if you wish to cite from it.

http://eprints.gla.ac.uk/172708/

Deposited on: 7 November 2018

Enlighten - Research publications by members of the University of Glasgow http://eprints.gla.ac.uk 


\title{
Sites of memory in the Irish landscape? Approaching ogham stones through memory studies
}

\begin{abstract}
The nexus between landscape, identity formation(s) and cultural memory has long been of interest to archaeology, cultural geography and other disciplines in the humanities. This article suggests that in medieval and early modern Irish texts, the depiction of monuments addresses precisely this complex relationship. On the basis of close readings of textual excerpts and a critical engagement with Pierre Nora's idea of lieux de mémoire it will be argued that the cognitive interplay between literary-imagined and archaeological-material monuments enabled the medieval Irish literati to situate themselves within the world they inhabited both spatially and culturally. The article thus contributes substantially to our understanding of the material aspects of social remembrance and advocates the potential benefits of including the extremely rich Irish textual and archaeological sources into broader, interdisciplinary discussions.
\end{abstract}

\section{Keywords}

Lieux de mémoire, Pierre Nora, ogham stones, medieval Irish literature, medieval Irish sagas, medieval and early modern memory cultures, landscape, landscape archaeology

\section{Author}

Dr Sarah Künzler

Celtic and Gaelic, University of Glasgow

Office 128, Gregory Building

00441413301758

Sarah.Kuenzler@glasgow.ac.uk 


\section{Sites of memory in the Irish landscape? Approaching ogham stones through memory studies ${ }^{1}$}

Ireland is particularly rich in monuments, whether prehistoric cairns and hill forts, medieval ring forts and souterrains, or memorials to the violent outbursts of the early modern and modern period. ${ }^{2}$ Among these are the comparatively unassuming stone pillars incised with short patronymic formulae in the ogham/ogam alphabet (ogham stones), inscribed over one and a half millennia ago. From the emergence of vernacular textual culture in Ireland around the $8^{\text {th }}$ or $9^{\text {th }}$ century $\mathrm{AD}$, these stones are also mentioned in a variety of textual sources, from medieval 'heroic sagas', legal material, and Classical Modern Irish poetry (in Irish) to modern-day children's literature and fiction novels (in English).

Although ogham stones are not frequently mentioned in these texts, their appearance in new compositions even of the early modern and modern period suggest that they remained part of the literary vocabulary across temporal and cultural shifts. This article examines references to ogham stones in medieval literary (i.e. non-legal) Irish-language texts preserved in manuscripts from the $12^{\text {th }}$ to the $16^{\text {th }}$ century and two later compositions, a saga from the $16^{\text {th }}$ or $17^{\text {th }}$ century and an $18^{\text {th }}$-century poem. In all of these, ogham stones are part of formulaic descriptions of pre-Christian burial rites, marking an ancestral presence embedded in the landscape and inviting remembrance of the 'deep time' of which the texts narrate. ${ }^{3}$ The aim is to map the 'workings of cultural memory' in pre-modern and early modern Irish culture by outlining the texts' engagement with the past and the landscape embodying it, an approach which has 
recently transformed our understanding of medieval Scandinavian culture (Glauser, 2000, 2014; Hermann, 2014; Lethbridge, 2016).

The article develops its analytical approach through an engagement with one of the most influential concepts in memory studies, Pierre Nora's lieux de mémoire ('sites of memory'). A critical correlation of Nora's ideas with medieval and early modern (c. $9^{\text {th }}-18^{\text {th }}$ century) Irish texts suggest that despite considerable cultural and temporal differences from Nora's État, shared symbols evoked cultural identity long before nation states emerged across Europe. Furthermore, it indicates that such symbols function as part of memory cultures, an observation which questions Nora's (1989: 7) assumption that lieux de mémoire emerged in the absence of true milieux de mémoire.

In its focus, the approach reflects Nora's (2001: viii) call to investigate 'the principal loci (...) in which this memory had become embodied (...).' Yet while Nora's lieux at times appear to struggle with the relationship between the physical and the symbolic, in the case of the ogham stones, stones and texts may coalesce in creating sites of memory. The pre-modern sources also draw attention to an aspect which Nora and the contributors to his volumes left largely unaddressed: the cultural mediation of lieux de mémoire, and their possible 'biographies', to appropriate a phrase from landscape archaeology (a field which has long engaged with the role of monuments as sites of cultural identity). ${ }^{4}$

To contextualise the analysis, it is necessary to first outline some central ideas of Nora's lieux de mémoire and to introduce the archaeological ogham stones that ostensibly inspired the texts. Thereafter, a selection of texts preserved in manuscripts from the $12^{\text {th }}$ to the $18^{\text {th }}$ century will be discussed through contextualised close 
readings. ${ }^{5}$ All are written in Irish and, apart from one early modern poem, are secular narrative compositions written in prose or prosimetrum ('sagas'). ${ }^{6}$ The findings will then be contextualised with recent work on the mnemonic value of archaeological monuments to address the role of imagined and material permanence in memory cultures. This allows for a critical analysis that is both historically sensitive and responsive to its sources, as well as conceptually attuned to influential thinking in memory studies. By avoiding a simple 'transfer' of concepts onto pre-modern sources but instead outlining possible points of connection, the article seeks to demonstrate that powerful and complex symbols produced within milieux de mémoire shaped pre-modern ideas of identity and belonging, and that landscapes - both lived-in and narrative ones were central to how these were socially and culturally constructed. ${ }^{7}$

Referencing Nora's lieux de mémoire stands in line with a wealth of studies on sites of memory conducted on national, European, and even pre-modern sources (e.g. Françoise and Schulze (2005) for Germany; Kreis (2010) for Switzerland; Olschowsky et al. (2011) for Eastern and Middle Europe; Den Boer et al. (2012) for Europe; SteinHökeskamp and Stein-Hökeskamp (2010) for Greek and (2006) Roman Antiquity; Schneidmüller (2006) for the European Middle Ages). Operating on a much smaller scale, the article presents a single case study, formulated on sources hitherto largely inaccessible to interdisciplinary audiences but able to contribute a valuable comparative perspective to memory studies.

It also explicates an engagement with concepts from memory studies in Celtic studies (the study of Irish-language sources). While the role of memory in pre-modern Irish culture has been acknowledged (e.g. Johnston, 2013), with the exception of the 
contributions to the edited volume by Rekdal and Poppe (2014) and the work of Dagmar Schlüter (2010a/b, 2014a/b), most theoretically-oriented engagement with Irish memory cultures refers to the modern period, English language sources, and to political contexts (e.g. Conway, 2010; Hackett and Rolston, 2009; Rolston, 2010; McAreavey, 2018; Leerssen, 1986; Pine, 2010; exceptions being the bilingual sources of Ó Tuama, 1985; and Frawley, 2005).

In opening a new perspective on Irish culture, the continuous material and mental presence of these monuments across temporal, linguistic and political boundaries is especially worthy of attention, as it implies that the stones are meaningful across cultural shifts and for different memory cultures and nourish a (by no means stable yet distinct) Irish cultural identity centuries before ideas of nation(alism) emerge. Including ogham stones into a broader discourse can thus contribute to our understanding of the forces which shaped cultural identities in the pre-modern period, and highlights the role mnemonic sites played in such processes. This illuminates historical developments of memory cultures by addressing modes of mediation and hence adds to the empirical scope of memory studies.

\section{Lieux de mémoire and identity formation}

Les lieux de mémoire (1984-1992) ranks amongst the most influential scholarly works of the past century. Although Nora's own understanding of the concept fluctuates over time, he characterises a lieu de mémoire as 'any significant entity, whether material or non-material in nature, which by dint of human will or the work of time has become a symbolic element of the memorial heritage of any community (in this case, the French 
community)' (1996: xvii). The vague nature of this definition has been openly criticised (e.g. Hahn and Traba, 2008), as it neglects to address how a 'significant entity' becomes a symbolic element, and what role these symbols play in a community's 'memorial heritage' ${ }^{8}$

In light of the substantial criticism the lieux de mémoire have received (Ho Tai, 2001; Marchal, 2003; Hahn and Traba, 2008; Kreis, 2010 amongst others), it is valid to ask what the concept can still contribute to memory studies. Yet what makes the lieux de mémoire particularly interesting from a medievalist's perspective is that they consist of diverse, heterogenic, case studies examining individual symbols that were meaningful for a particular group in society (see Ho Tai, 2001). For Nora (1996: xv) the case studies expose 'the places in which the collective heritage of France was crystallized, the principal lieux, in all senses of the word, in which collective memory was rooted, in order to create a vast topology of French symbolism.' By engaging with one such 'place' (i.e. site of memory) in texts composed by professional literati, it is of course not possible to draw conclusions about the topology of Irish symbolism, but it is possible to examine a particular mediation of complex mnemonic strategies.

Nora's open definition of the lieux is particularly attractive to consider in relation to medieval Irish culture and its competing (secular and ecclesiastical) power structures. Aleida Assmann's (2001: 122) assertions that Nora demonstrates that 'what steers the memory of the group is neither a "collective soul" nor an "objective mind", but a society with its signs and symbols' and that through 'these shared symbols, the individual participates in a common memory and a common identity' appears particularly apt for the complex and fluid Irish tradition. Her observation further draws 
much-needed attention to the participation of groups and individuals in identity formation, for which the texts were central points of reference. However, as Guy Marchal (2003: 13) remarks, both Nora's work and adaptations thereof generally focus on Rezeptionsgeschichte ('history of reception'), the effects of historical images, concepts, and ideas of the past ('Nachwirkungen von Geschichtsbildern, Begriffen und Vergangenheitsvorstellungen'). ${ }^{9}$ In seeking to discuss the mental images which form and sustain the role of ogham stones as sites of memory, this article aims to redress this imbalance and places a clear focus on the media of remembering: texts and stones.

Material differences in the lieux are inherent already in the original approach. The case studies by Nora and his contributors examine geographical places or loci, historical figures, monuments and buildings, literary and artistic objects, emblems, and commemorations, 'all of which are the result of an imaginary process that codifies and represents the historical consciousness of "quintessential France" (Kritzman, 1996: x). In outlining their essence, Nora (1989: 19, see also 1990: 19) states that

lieux de mémoire are simple and ambiguous, natural and artificial, at once immediately available in concrete sensual experience and susceptible to the most abstract elaboration. Indeed, they are lieux in three senses of the word - material, symbolic and functional.

Nora's assertion that the lieux are at once available in sensual experience and symbolically elaborated is a valuable starting point from which to discuss how in the case of the ogham stones, material and cognitive aspects of remembering coalesce.

In Celtic studies, a critical engagement with concepts from memory studies has recently been encouraged by Maria Tymoczko (in relation to Jan Assmann's cultural 
memory). Tymoczko (2014: 28) argues that the Irish material 'is superb for illustrating the workings of cultural memory and thus for interrogating theories of cultural memory' but simultaneously draws attention to the need for a critical and close comparison of, rather than a mere application of, concepts to sources. Her opinion is reflected in other disciplines, as Legg (2005: 494) proposes that in cultural geography, 'terms and concepts [of the lieux de mémoire] can be utilised effectively, but only if they are heavily qualified', and, one might add, individual points are discussed in some detail.

One such matter is Nora's dogma (1989: 7) that lieux de mémoire replace true milieux de mémoire, and that the former emerge through a lack of the latter: 'there are lieux de mémoire because there are no longer milieux de mémoire, real environments of memory'. Erll (2011: 23) consequently interprets Nora's sites of memory 'as a sort of artificial placeholder for the no longer existent, natural collective memory'. In attempting a definition, Nora (1996: 1) proposes that milieux de mémoire were 'settings in which memory is a real part of everyday experience.' Nora therefore somewhat simplistically juxtaposes the modern period with a time in which memory was allpervasive: 'if we still dwelled in our memories, there would be no need to consecrate sites embodying them' (1996: 1).

Georg Kreis (2010: 328) criticises this simplistic dualism and proposes that lieux de mémoire were present even in pre-modern milieux de mémoire. Kate Chedgzoy, Elspeth Graham, Katherine Hodgkin and Ramona Wray (2018: 7) further stress that 'the memory cultures of the early modern world were complex, self-conscious and highly mediated, rather than organic and unreflective'. This is certainly applicable to the Irish 
sources also, and stressing this fact in the analysis will enable a broader discussion on common assumptions about the value of pre-modern cultures for memory studies.

Medieval Irish literati and later secular scribes certainly worked within a culture that was steeped in mnemonic discourses to which annals, genealogies, literary texts and the extensive place-name lore (Dindshenchas, see below) bear testimony. The longevity of these into the early modern and modern period (particularly in folklore) suggests that rather than being mere scholarly pursuits, they functioned within a culture in which memory was part of lived experience. Yet within this apparent milieu, we encounter sites on which negotiations of collective memory occur and become visible and tangible. These are by no means mere placeholders but enable a communal experience of a remembered past, which in turn facilitates a sustained engagement with the textual and the material tradition for identity construction.

Yet perhaps the most notable point of divergence between my own sources and Nora's is that unlike Nora's État, pre-modern Ireland had no unified nation state and no imposing central(ised) force in a political sense. Rather, it consisted of unstable and fragmented political territories and alliances, with secular and ecclesiastical competition for power. A lack of centralised political power does, however, not categorically exclude feelings of cultural unity, whether in a religious or cultural sense. Thomas Charles-Edwards (1998: 77) argues that despite its fragmentation into different kingroups (cenéla), certain sources evoke a (linguistic-cultural) 'unity of the Irish people as a whole.' In similar vein, Donnchadh Ó Corráin (1978: 4) showed that 'the Irish were profoundly conscious of themselves as a larger community or natio' and that 'their learned classes were preoccupied with this very notion'. Many sources betray an 
imaginative engagement with origin stories (central to medieval identity formations), and the ogham alphabet can certainly be viewed as a cultural indicator of a 'distinctly Irish' culture. The Irish material may thus provide an excellent opportunity to challenge some of Nora's assumptions, and to critically engage with the role of sites of memory in an environment that reveals a very different reflection on its cultural identity.

\section{Enter the stones: a brief introduction to ogham and ogham stones}

While the erection of standing stones appears to be an (almost) universal phenomenon, the inscription of said stones with an alphabet that has a strong cultural specification 'localises' these stone to a particular culture (e.g. the rune stones in Germanic culture(s)). The ogham script is first attested on stone pillars in Ireland and in areas of the British Isles where Irish influence is attested. ${ }^{10}$ The inscriptions reflect the language of between the $5^{\text {th }}$ and the $7^{\text {th }}$ centuries AD (McManus, 1997: 78-100). ${ }^{11}$ In Ireland, ogham stones are found in a variety of contexts: as freestanding pillars or re-used over centuries 'as building stones and lintels, built into souterrains, ring forts, churches, outhouses and other structures' (Swift, 2002: 129; see also Moore, 1998: 23). ${ }^{12}$ The writing usually runs on the right-angle of the stone (i.e. along the arris, see appendix 2) and consists of strokes and notches (see appendix 1) placed relative to the stemline/arris. ${ }^{13}$

The origin of the script has been the subject of considerable debate. ${ }^{14}$ Damian McManus (1997: 1), who has produced the most extensive study of script, language, and stones, concludes 'that the alphabet was designed for the Irish language' and 'it is likely that its framers were Irish and probable that they resided in the south of the 
country, possibly in the fourth century'. Whoever they were, the framers were trained in Latin grammar and possessed the sharp analytical skills necessary to apply their knowledge to their native language. Fionnbarr Moore (2010: 9) stresses that ogham inscriptions on stones show a remarkably standardised script and orthography, a fact which points to a consistent training of the 'scribes' and implies a desire for uniformity.

Two medieval origin legends for the alphabet have come down to us, one mythological in outlook, the other rooted in a biblical framework referencing the Tower of Babel. ${ }^{15}$ Neither is of any historical value, but both stress that ogham was invented by the Irish, specifically for the Irish language. Even in literary texts, the script is thus perceived as part of a distinctly Irish culture, and seemingly emerges in a deep past in which Ireland is populated by ancestral figures, or in Biblical times thought to be contemporary to the 'deep mythical past' of Ireland. ${ }^{16}$

There is, however, a conspicuous regional distribution of the extant archaeological stones. Of the 360 stone pillars inscribed with the ogham alphabet currently recorded in Ireland, c. $70 \%$ are located in the South-west. ${ }^{17}$ For Johnston (2013: 13) this suggests that 'ogam was strongly associated with certain people' and may 'have acted as communal identifiers'. While this is probable for the archaeological material, literary sources describe the erection of ogham stones all across Ireland, ostensibly understanding them as a pan-Irish phenomenon.

Most (early) inscriptions on archaeological stones are short and remarkably formulaic. ${ }^{18}$ They consist only of a male name in the genitive and a patronymic and/or tribal affiliation, i.e. 'of X son of Y (of the tribe of Z)' (see appendix 2). 19 'Monument', 'stone', 'grave', 'name' or 'property' is hence implied before the name. ${ }^{20}$ Fionnbarr 
Moore (1988) claims that the archaeological ogham stones could have marked anything from a sacred place, a burial ground, a grant or title to land, a tribal boundary, a church foundation, a hermitage or a combination of these, and overlapping functions over time are likely.

Although ogham stones are explained predominantly as burial markers in the literary texts (albeit not in the legal material), few archaeological ogham stones have been reliably recorded in association with individual graves (Charles Thomas, 1971: 98; Mallory, 1992: 130). ${ }^{21}$ Ogham stones could, of course, have marked entire family burial grounds (fertae) or cremation burials (Swift, 1997: 31), factors which may inhibit the identification of stones with individual burial remains. Yet the burial practices described in the sagas - one man or a small group being inhumed, a stone being placed over his/their head, the ogham inscription on it bearing his name - do not appear to be supported by the archaeological evidence, making it likely that the texts (post-dating the archaeological stones) to some extent imaginatively engaged with the stones. ${ }^{22}$

Ogham stones may have served several interrelated purposes. Moore (2010: 10) argues that they 'may have functioned as memorials, grave-markers or territorial markers' - all roles linked to mnemonic aspects. McManus (1997: 165) explicates the role of the stones as markers of land and boundaries but raises the point that since burial seems to have taken place at boundaries, 'it is possible that the two functions were complementary' (see also Moore, 2010: 15). In this case, the stones could enforce kin (or group) identity by providing a visible and tangible connection with the ancestors, but simultaneously mark ownership of land, fulfilling, as Johnston (2013: 12) phrases it 'territorial, genealogical and charter-like roles' (see also Charles-Edwards, 1998). 
Despite the open debate on their function (and the above-cited roles do not need to be mutually exclusive), ogham stones clearly provided material mnemonic connections to the past and served to integrate this past into the present experience of the landscape, an endeavour in which the literary texts readily took part.

\section{Imagining pagan times: ogham stones in sagas and poetry}

If one looks at modern Irish literature in English (Seamus Heaney) or Irish (Nuala Ní Dhomhnaill) or at folklore, it would appear that the inhabitants of Ireland are still particularly preoccupied with places, and with an 'Irish sense of place' (Sheeran, 1988). ${ }^{23}$ Such an interest is evident already in medieval literary sources, in which the landscape, its names, and the monuments therein are intimately connected with Irish culture, are a permanent, tangible reflection thereof. The analysis of ogham stones from a memory studies perspective must acknowledge such an enduring engagement, and the sense of cultural permanence it evokes. Perhaps more so than uninscribed stone pillars, ogham stones thus symbolise a distinctly Irish presence on the land because they reference a script that is intrinsically Irish, and was devised for the Irish language in the deep past of biblical or mythological times, and because it is Irish names that are inscribed in it.

The belief in the great antiquity of both the ogham script and the Irish language is expressed in written sources from the Old Irish period $\left(7^{\text {th }}-9^{\text {th }}\right.$ centuries $)$ to the native schools of Classical Modern Irish $\left(17^{\text {th }}\right.$ century). ${ }^{24}$ However, things get more complex if we approach ogham stones through their function as monuments within the texts. Written sources of the medieval period outline a rather conspicuous divide. Legal 
material commonly relates ogham stones to territorial claims (proof of title to land, McManus, 1997: 163-166). On the other hand, non-legal texts (such as 'sagas' and poems) see them predominantly as grave-markers erected as part of ostensibly preChristian burial rites and associated with individual (i.e. personal) inhumation burials (see also McManus, 1997: 153-166). Swift (1997: 42) points out that across pre-modern Irish texts (both legal and literary), ogham stones in fact fulfil 'the same three purposes that are indicated for stone pillars in the Bible: that is, as memorials for the dead, as boundary markers and as proclaiming the ownership of estates', but the clear focus on burial rites in the sagas forms the background to the following analysis.

Today, the sagas are viewed as complex and at times critical products of a Christian society with a deep-seated interest in its past, and in how that past is reflected in the present. Up until the $12^{\text {th }}$ century, Irish secular texts were produced in monastic contexts by trained Christian scribes (thereafter the production switched to families) and hence many of the texts discussed here would have first been committed to writing in monastic contexts. Today, these texts are no longer seen as offering accurate reflections of the time in which their narratives are set (often pre-Christian). Rather, the 'sagas' are mapping out an Irish pre-history by drawing on their native tradition (and landscape), Christian historical writings, (Orosius, Eusebius), biblical influence (see McCone, 1990) and even on their literary imagination, as Ruairí Ó hUiginn (1992: 49-52) outlines (see also Herbert, 2007 and 1988).

To delineate the role of ogham stones as sites of memory, it is not strictly necessary to resolve the question of whether the literati 'were familiar with the practice of erecting stones bearing memorial inscriptions in Ogam, though this had long since 
died out in their own day' or whether they were 'projecting into the past the familiar custom of doing the same in conventional script and accommodating to the time-scale of the story by having the inscription written in Ogam, which was known to them to be of considerable antiquity' (McManus, 1997: 155). In fact, Christian grave-slabs at the time (bearing Latin inscriptions) do not present as clear a parallel as McManus' comment would suggest, and it is unclear how much exactly the medieval literati knew about the (original or changing) function(s) of ogham stones. ${ }^{25}$ However, except for several references in which ogham is written on sticks for communicating short messages, the sagas generally depict ogham as 'a vehicle for memorial inscriptions' on stone (McManus, 1997: 154), and hence as a script intimately linked to monumental, memorial practices. ${ }^{26}$

The strong link this creates with their ancestral pasts - the ancestors marking and altering the landscape with memorials to their dead - saw the landscape as inscribed with the heroic and/or ancestral actions narrated in the sagas. This enabled a participation in a cultural identity that was expressed spatially and mentally (on a diachronic level), engaged with the origin of customs, and continuously made the past present. As is by no means unusual for medieval Irish literature (or the medieval tradition at large), it is an etymologizing origin legend - in this case part of a genealogy - which claims to narrate the earliest use of an ogham stone as grave-marker. ${ }^{27}$

The genealogy is found in the $12^{\text {th }}$-century manuscript the Book of Leinster (fol. 320c 27-30), although it was probably composed earlier. It says that the pre-historic king of Munster, Cétchuimnech mac Áeda Deirg, was the person for whom memorials in ogham were first erected in Ireland: 'Cétchuimnech, for whom monuments in ogham 
were first made/erected in Ireland' (McManus, 1997: 155). ${ }^{28}$ The anecdote appears to be a creative etymology on the king's name - which may be translated as 'firstremembered' - and is revealing in many ways. First, it associates the remembering of a specific individual with a memorial in ogham. Second, the origin of the custom of erecting ogham stones is firmly situated in the pagan era, i.e. in the deep time of which most of the sagas narrate. Third, the origin of the custom is located geographically in the south-western province of Munster, where c. $70 \%$ of the archaeological stones are extant today. The short passage thus outlines various interesting aspects, such as implicit connections to place, to tradition, and to memory.

This triad is also prominently outlined in the Finn Cycle tale Acallam na Senórach ('The Colloquy of the Ancients', early $13^{\text {th }}$ century) ${ }^{29}$ It narrates how St Patrick meets the sages Caílte and Oisín and how they travel around Ireland together, the sages relating the origin of place-names and stories about their previous adventures to the saint, who has their accounts written down. Caílte and Oisín belonged to Finn mac Cumaill's (Finn MacCool's) war-band but miraculously survived hundreds of years into the Christian period. They therefore present a direct link to, and have personal knowledge of, the 'pagan heroic period' of which many literary texts narrate. On their journey, Ann Connon (2014: 21) observes, 'the composite landscapes created by these places tell a story', a story which is rooted in personal memory and links acts of remembering with the present shape and names of the land.' Within one of these narratives, Caílte describes a typical funeral scene: 'They were placed in the grave after that, their stone was raised and their name was written in ogam. ${ }^{30}$ 
Such in-tales telling of pagan times within a frame-narrative set in Christian times ( $5^{\text {th }}$ century) narratively link these two 'timescapes', and also relate it to the time of the composition of the text $\left(13^{\text {th }}\right.$ century). The action in the past (in-tales) effects the present (frame-tale), with toponyms (place-names) and memorial monuments such as ogham stones being encountered by the saint and other figures inhabiting Ireland at the point of Christianisation. This immediate experience prompts questions about the past and toponyms and monuments such as ogham stones thus provide both cognitive and material links between past and present. ${ }^{31}$

It may be implied that toponyms and monuments were both important and intelligible in the $13^{\text {th }}$ century when the texts was composed precisely around such sites of remembering that evoke a landscape reflecting a cultural identity. The texts thus add a literary dimension to Denis Cosgrove's (1984: 11) assertion that 'in landscape we are dealing with an ideologically-charged and very complex cultural product' which simultaneously incorporates material and symbolic experience. This suggest that textual and lived-in landscapes oscillate, and draw on each other in forming sites in which the thus produced memory comes to crystallize. ${ }^{32}$

The phrase used in Acallam na Senórach is indicative of a highly formulaic depiction of pagan burial rites in early Irish texts, which only slightly varies in terminology (McManus, 1997: 154). The long 'heroic saga' Táin Bó Cúailnge ('The Cattle Raid of Cooley'), for example, was probably first written down around the $9^{\text {th }}$ century, but is preserved in its earliest form in a $12^{\text {th }}$-century manuscript. Centuries before Acallam na Senórach, depicts a very similar reference to the burial of a warrior 
named Etarcomol: 'then his grave was dug and his headstone was planted in the ground, his name was written in Ogam and he was mourned. ${ }^{, 33}$

However, texts may add short etymologizing origin legends to this, frequently connected to toponyms and place-lore. Aidedh Ferghusa ('The Death of Fergus (mac Léite)') is a death-tale of unknown date preserved in a $16^{\text {th }}$ - and an $18^{\text {th }}$-century manuscript. ${ }^{34}$ It states that after Fergus' death, 'his grave was dug, his name written in ogham and his lamentation-ceremony all performed; and from the monumental stones [uladh] piled by the men of Ulster this name of Uladh [Ulster, a province] had its origin. ${ }^{35}$ The cairn erected in addition to the inscription in ogham is linked to a creative etymology much like the one about Cétchuimnech and binds monuments, land, toponym and people together. This interest is widespread in Irish place-lore (Dindshenchas), short narratives in prose or verse explaining how a place-name was created. Much like ogham stones, place-names are therefore a result of the on-going impact of an Irish presence on the land. With a wit that rivals Isidore's Etymologiae $\left(7^{\text {th }}\right.$ century), the Dindshenchas form a 'mythological geography of the country' (Sjoestedt, 1949: 24) much as the ogham stones form a mythological archaeology. ${ }^{36}$

Tochmarc Étaine ('The Wooing of Étaín', probably of $9^{\text {th }}$-century origin) is a tale with a complex and fragmented transmission history, and one of the few texts which does not narrate the erection of an ogham stone in real time or retrospectively. ${ }^{37}$ Étaín is married to king Eochaid Airem but the king's brother Ailill falls in love with her and is consumed with love-sickness. ${ }^{38}$ When Eochaid has to leave the royal court, he instructs Étaín to care for Ailill and in the event of his death to 'dig his earthly grave, to raise his standing-stone and his pillar and to inscribe his name in Ogham. ${ }^{39}$ The 
ogham inscription is only mentioned in the longest version of the tale, but it adds to the otherwise much shorter descriptions of the burial rite befitting a king's brother. ${ }^{40}$ Susan Leigh Fry (1999: 138) states that across sagas, references to ogham stones erected in burial rituals 'indicate how a medieval audience would have wanted to believe the great legendary Irish kings, queens and warriors of a "golden age" had been buried, and what would have been considered appropriate markers for their graves', and Tochmarc Étaine clearly supports such an argument.

It is telling that sagas generally narrate the erection and inscription of the stones (Tochmarc Étaine being a rare exception), but that no memorial engagement (mourning, visiting of stones by relatives etc.) is described after the burial ceremony. However, Joanna Huckins MacGugan (2012: 189) points out that medieval Irish texts more often 'emphasise the creation of sacred space' [to which the she adds burial sites, sk] rather than their re-use. It should also be briefly mentioned that in both Aidedh Ferghusa and Tochmarc Étaine, the reference to the burial ritual and to ogham stones is only found in later versions of the text, an observation which could reflect their transmission history or perhaps a conscious later engagement with these memorial stones for a variety of reasons, for instance to add an archaic, perhaps even authentically pre-Christian touch to the narratives. ${ }^{41}$

The depiction of ogham stones as grave-markers in literary texts is continued in the modern period as part of the formulaic burial rite. Oidheadh Chloinne Tuireann ('The Fate of the Children of Tuirenn') is a tale echoing those of the Mythological Cycle yet dated to the $16^{\text {th }}$ or $17^{\text {th }}$ century. ${ }^{42}$ The hero Cian is killed and improperly buried by the three sons of Tuireann. Cian's own son, Lug, later finds his grave and has 
him exhumed. Cian is briefly revived and relates the manner of his death before being reburied properly. This time, the burial ritual includes an ogham-inscribed stone as a grave-marker: 'Cian was again placed in the grave after that; his tombstone was erected over his tomb, and his dirge was sung, and his name inscribed in ogham. ${ }^{43}$ Although an early modern composition, Oidheadh Chloinne Tuireann tells of the 'mythological time' also depicted in Tochmarc Étaine and in which the invention of the ogham script is also situated. A conscious reference to ogham stones at this period suggests that they were part of a literary Irish construction of the past that was continuously meaningful to both the composers of the texts and their audience.

An even later text, Laoi Oisín ar Thír na nÓg ('The lay of Oisín in the land of Youth'), is an example of modern poetry building on the Finn Cycle material and draws on motifs belonging to the oldest elements of early Irish literature. ${ }^{44}$ It was attributed to the famous $18^{\text {th }}$-century Co. Clare poet Micheál Ó Coimín by its first editor, Brian Ó Luanaigh. ${ }^{45}$ Like in Acallam na Senórach, the Fenian warrior Oisín (son of Finn MacCool) converses with St. Patrick. Oisín had left his father's warrior-band to follow a mysterious woman to Tír na $n O ́ g$ ('The Land of Youth'), where time stands still.

When Oisín returns to Ireland, he finds that several centuries have elapsed. In the now Christian Ireland he encounters St. Patrick and recounts his memory of olden (read: pre-Christian) times. In stanza 77, he describes the burial of a heathen giant:

The giant grim we buried him

Deep down in earth in widest grave -

We raised a stone his grave to note

And his name we wrote in Ogham-craev. ${ }^{46}$ 
Like Acallam na Senórach, the laoi has a three-fold layering in terms of temporal arrangement, each separated by several centuries: the pagan time of the in-tales (i.e. the stories recounted from memory), the newly Christian time of the frame-tale (i.e. the dialogue between Oisín and St Patrick) and the $18^{\text {th }}$ century, when the laoi was composed. And it is in the first of these that the erection of ogham stones is situated even if we may imply that the trope was still a meaningful literary feature in the $18^{\text {th }}$ century, not least because the archaeological stones could be experienced still.

\section{Ogham stones in texts as material, symbolic and functional entities}

That the $18^{\text {th }}$-century poet would consciously draw on the ogham burial formula when narrating of pagan times shows the longevity and cultural value of the motif and allows the story, and the text, to stand (and be understood) as a continuation of earlier material. In this case of an obvious re-use of the motif, a key feature which Kreis (2010: 7) has identified for lieux de mémoire becomes apparent: that they are part of the past but still 'present', and unite a historical dimension with acts of remembering. Even if elsewhere, as McManus (1997: 156) argues, ogham may be used in later compositions 'in the looser sense of "written Irish", this does not diminish the cultural distinctiveness and the mental connection with the 'ogham' stones it evoke in such texts.

Such references may be part of a more encompassing attempt of the medieval literati to engage with the stone monuments they perceived around them, and of the early modern composers to create an authentically pre-Christian atmosphere for the narratives. Understanding the stones as ancestral burial markers created a convincing link to the warriors populating the sagas. It also demonstrated that these very forebears 
had claimed the land both spatially and culturally: the landscape, as Lethbridge (2016: 56), phrased it for the Norse sagas, became 'imprinted' with their presence.

In doing so, the ogham stones created a culturally binding force akin to Nora's lieux de mémoire. Furthermore, they appear to draw on all three categories which Nora outlined for the lieux de mémoire, namely physical, symbolic and functional meaning. To recall Nora (1989: 19, see also 1990: 19):

lieux de mémoire are simple and ambiguous, natural and artificial, at once immediately available in concrete sensual experience and susceptible to the most abstract elaboration. Indeed, they are lieux in three senses of the word - material, symbolic and functional.

On a symbolic level, ogham stones are symbols of a great heroic past and thus create a tangible link between said past and any given present. On the functional level, they act as burial markers within the sagas and show how a conscious engagement with the lived-in landscape may influence literary tropes.

The dual existence of ogham stones as evoked monuments in textual production and as a material presence in the lived-in landscape is a key point in their role within Irish memory culture. Engagement with the ogham stones oscillates between the concrete sensual experience and the symbolic: If one allows for the mental image of the literary stones to build on the material archaeological stones in an imaginative way, and for the sensual experience of the archaeological stones to be evoked mentally in the engagement with the sagas, they even operate with two 'materialities': one made of (material) rock, the other of a mental concept of 'stoneness'. Both, it may be argued, conjure images of permanence and memory, embodied in their interaction. 
It is the mental interaction between the lived-in and narrative landscapes of the texts that allows for the production of such medieval a site of remembering. In looking over the edge of the manuscript folii and considering the memory culture of which both archaeological and literary ogham stones formed part, one may begin to grasp the significance these monuments held over several centuries. Although their mentions may be few, the fact that they occur from the $9^{\text {th }}$ to the $18^{\text {th }}$ century and specifically at points when texts refer to a distinctly pre-Christian, 'deep time' suggests that the cultural permanence which they made tangible formed part of both diachronic and synchronic sites of remembering. Far from being the remnants of milieux de mémoire, they are the threads that hold it together.

\section{Monument, memory, and lieux: some comparative remarks}

Similar ideas have been proposed in other disciplines. In landscape archaeology, the mnemonic role of monuments and the processes by which monuments trigger remembering on either a personal or a cultural level have been foregrounded. Various studies outline how the landscape comes to embody material prompts to remember (see Hall, 2015: 192-197; Andres Andrén, 1993, 2013; Ní Ghrádaigh, 2015: 231-236). As Anouk Busset (2017: 16) phrases it: 'Stone monuments are about memory: they can be used to join the past to the present, they commemorate and they endure. ${ }^{47}$ In relation to British sources, Williams (2006: 144-145) proposes that funerary monuments both 'create memorable sensory engagement for the mourners' and 'connected retrospective pasts with prospective futures', a comment that is highly applicable to the literary sources discussed here. 
Williams' (2000: 158) earlier argument that monuments participate in a 'commemoration of kin, ancestry and group identity' likewise fits the sources remarkably well. Yet such overlapping commemorative functions, often linked to the re-use of monuments, are at times hard to document for the pre-historic period. In the case of the ogham stones (or the Scandinavian rune stones), it is, however, possible to document the pluralistic and heterogenic mental engagement with these monuments in the medieval period through textual analysis. Although in itself a limited endeavour, this approach may fill an important gap in the study of these monuments, and draws attention to the media which anchored the monuments in cultural memory.

The material aspect of such monuments plays an important part in their mnemonic role. Andrew Jones (2007: 3) observes that '[a]s physical materials, artefacts provide an authentic link to the past and as such can be re-experienced'. This is relevant for the cultural coordinates of the society for as Jones (2007: 220) concludes, '(b)y addressing living rock as if it were the traces of past events (..), people situated themselves historically in the landscape'. Textual analysis can contribute to such discussions from a literary perspective, at least for the medieval and early modern period. By operating from the above-mentioned dual perspective and creating an intimate interplay between archaeological and literary stones it becomes possible to focus on the 'workings' and the 'media' for such mnemonic cultures. This fills an important gap in our appreciation of the mnemonic functions of stone monuments because it allows us to trace how people engaged with the world around them, as well as with their literary tradition, through sties of memory. 
The tangible, material aspect in this must not be neglected, for as Siân Jones and Lynette Russell (2012: 275) propose, archaeological sites 'can play an important role in terms of providing the material dimension of the past to which people express their affiliation, sense of belonging, and social identity.' Even in texts, ogham stones are cognitively linked to such aspects precisely because, as Jan Erik Rekdal (2014: 114) stresses, the archaeological 'ogham stones represent material perceived of as more solid than parchment'. Whether or not the earliest textual mentions of ogham stones are based on genuine knowledge of pre-Christian burial rituals (and this is debatable), at least the early modern re-uses of them are testimony to an effort to put 'the puzzle back together: inventing the past to fit the present, or, equally, the present to fit the past' (Fentress and Wickham, 1992: 201).

Such a juxtaposition of narratives and the lived-in landscapes from a mnemonic perspective has also been addressed in neighbouring disciplines. Glauser (2007: 20) argues that in Icelandic saga literature 'it is first and foremost the landscape and the events localised in it which play the decisive role as guarantors of memory'. Pernille Hermann (2014: 28) adds that mnemonic places in Old Norse-Icelandic literature most obviously reflect the spatial environment of the Icelandic landscape, and it is not least the topography of saga-texts and their literary mapping of the natural and cultural landscape which is crucial when considering the relation of saga-texts to mnemonic places.

Emily Lethbridge (2016: 56, 76) makes very similar arguments by asserting that in the case of medieval Icelandic sagas, people 'imprinted their lives' on the landscape but, 
simultaneously, also 'made places memorable' and fixed them in their minds. This suggests that it was not only modern nations which 'consecrate particular sites as crystallising "memory"' (Stephen Legg, 2007: 459) but that medieval cultures in fact reveal similar concerns, made expressible and tangible through an engagement with the landscape in culturally specific terms.

Such studies unearth a memory which is not part of medieval theories of ars memoriae (see Carruthers, 1990), but borne out of an engagement between medieval thought and the inhabited landscape. Exploring the cultural significance of monuments such as ogham stones can add a valuable, different perspective to work that has focussed predominantly on geographies of power and politics (see, for example, Jones, 1999; Jones and Fowler, 2008; Jones and Harvey, 1999) and shows how well before the rise of modern nations, cultural identity was mapped out through sites of memory.

\section{Concluding remarks}

The foregoing arguments have proposed that ogham stones fulfil a variety of functions within the mnemonic tapestry of Irish cultural memory that can be more fully understood if linked to sites of memory. These stones contribute to a feeling of cultural identity and unity by successfully linking people and landscape, past and present, (Christian) literati or poets and 'their' ancestral (pre-Christian) 'heroes'.

In the case of the ogham stones, milieux and lieux are dependent on each other and in fact invigorate the longevity of the topos- a longevity which would hardly have occurred if the stones had not continued to be meaningful across cultural and political shifts. Across archaeological and textual boundaries, ogham stones are at once material, 
symbolic and functional sites of memory. Oscillating between the material and the imagined/narrated, however, they challenge a rigid distinction between the material and the immaterial and instead presuppose a cultural memory in which the perceptual and symbolic combine. Ogham stones are not merely narrative markers of pastness, but complex media within cultures of remembering. Engaging with the discursive constructions of the past emerging from such media can enhance our understanding of the relationship between physical and mental aspects of cultural memory (and its workings) and this successfully shifts attention to the processes of mediation (rather than singular receptions).

Such observations allow us to 'reconceptualiz(e) the relation between past and present' and outline 'an alternative to the supposed linearity and pastness of [modern, sk] history that takes the form of the persistence of an unresolved past into the present' (Chedgzoy et. al., 2018: 7). ${ }^{48}$ Breaching disciplinary, temporal and linguistic borders can lead to a more comprehensive understanding of the continuous re-investment of such monuments from the 'internal' perspective of the sources. This is necessary to outline how a culture situates itself both culturally and geographically, within its own tradition and on the land it inhabits. Further such dialogues are necessary to capture the scopes of such interactions, but not addressing such issues bears a real risk for continuing assessments of pre-modern memory cultures as organic and unreflective, rather than acknowledging that they are 'complex, self-conscious and highly mediated' (Chedgzoy, et. al., 2018: 12). 


\section{Funding acknowledgements}

I would like to thank the Swiss National Science Foundation and the British Academy for facilitating the research on which this article is based.

\section{Appendix}

Appendix 1: The ogham alphabet. Image courtesy of Katherine Forsyth, all copyright lies with her.

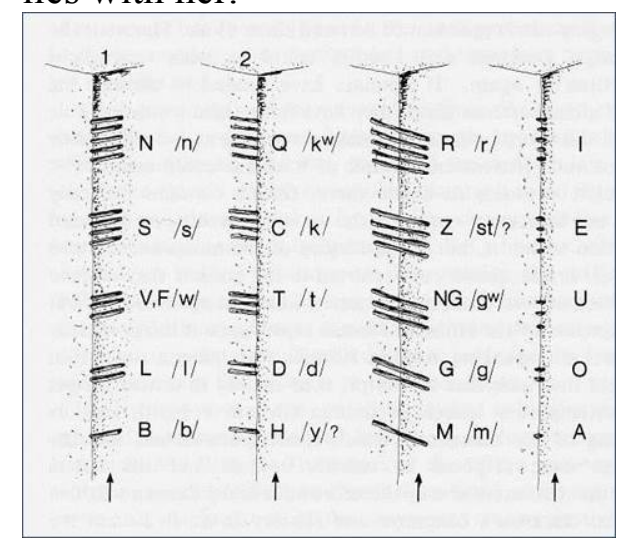

Appendix 2: Ogham stone on Dunmore Headland, Co. Cork, Ireland

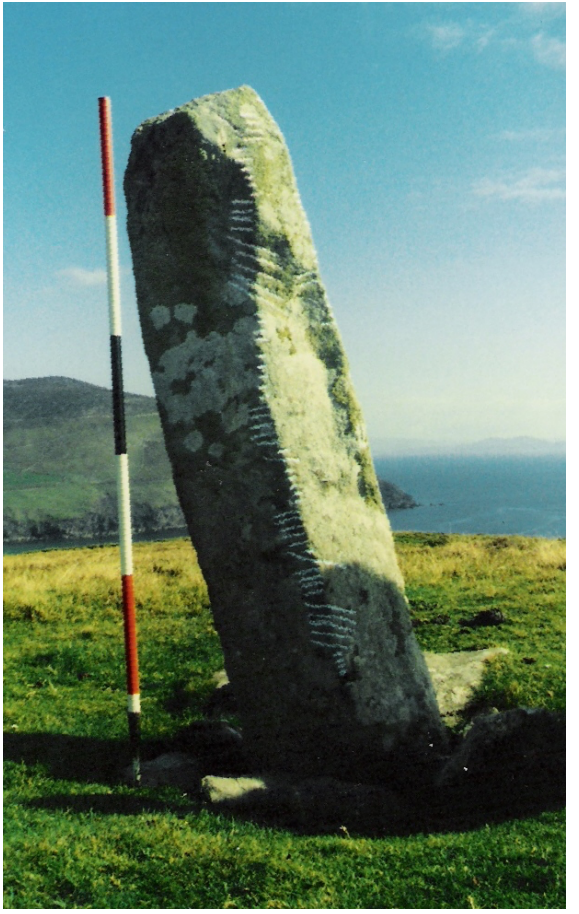

(picture courtesy of Damian McManus, all copyright lies with him. The ogham letters are traced with white chalk to improve legibility.)
Ogham stone at Dunmore (An Dún Mór) promontory fort, Co. Cork. Find location possibly original site.

\section{ERC MAQI MAQI-ERCIAS MU DOVINIA} 'of Erc son of Mac-Erce descendant (?) of Duibne'

The inscription is read upwards from the left bottom to the top, and then upwards in the same fashion again from the right.

Discovered in 1838, probably re-erected.

Macalister (1899: 279-280) states that a souterrain containing bones and a cross-inscribed stone had once been discovered on the headland on which the ogham stone now stands.

Description, transliteration and translation taken from the Ogham in $3 D$ project at the Dublin Institute for Advanced Studies.

https://ogham.celt.dias.ie/stone.php?lang=en\&site= Coumeenole\&stone $=178$._Coumeenole\&stoneinfo =inscription 
${ }^{1}$ I would like to thank Dr Katherine Forsyth and Prof Damian McManus for their comments on earlier
drafts of this article, and the anonymous reviewers for their equally helpful suggestions. All remaining errors are my own.

${ }^{2}$ O'Sullivan et al. (2014: 1) have identified 47,000 sites and approximately 120,000 monuments from the early medieval period (400-1100 AD) alone.

${ }^{3}$ This presents a complementary perspective to well-established studies of pre-modern memory cultures focussing predominantly on mnemotechnics (ars memoriae, see Carruthers, 1990; Yates, 1966).

${ }^{4}$ See Gosden and Marshall (1999) and Hall (2015). This focus 'breaks down the straightjacket of traditional periodizations (...) and, by revealing complexities within periods, disrupts cohesive, generalized definitions of the function and meaning of sculpture' (Hall, 2015: 183). See also Howard Williams (2006), Siân Jones (2011; Jones and Lynette Russell, 2012), Andrew Jones (2007) and David Petts (2003) on British stone monuments, and Christopher Tilley (1994) for a phenomenological perspective. In cultural geography, the work of Rhys Jones (1999 with Andrew Harvey; 2008) and Stephen Legg (2005) provides perhaps the closest parallel, despite their predominant focus on geographies of power.

${ }^{5}$ Close readings are indebted to post-structuralism and examine particular thematic foci in their individual narrative development. For medieval texts - complex cultural products at times incorporating centuries of re-writing and adapting - it is important to simultaneously establish the cultural, political and temporal background from which the texts emerged, and in which they were transmitted.

${ }^{6}$ Prosimetrum designates the mixture of prose and verse that is common in pre-modern Irish texts.

${ }^{7}$ Landscape, although a rather polymorphous concept both in reality and in science, is defined here freely as a multisensory experience of the living environment, an environment shaped by nature, human activity and animals. In Irish textual sources, the topographical, geomorphological and ecological features of a landscape are all seen as the result of human or divine presence as are cairns, forts, or standing stones. As such, the term landscape as applied here covers natural, human and animal influence on the visible land. As Denis Cosgrove (1984) argues, landscape appeals at once to the material and the representational, and it is this duality that the ogham stones foreground. See Schama (1996) for an in-depth analysis of landscape and memory.

${ }^{8}$ The issue of agency is briefly addressed by Schneidmüller (2006).

${ }^{9}$ All translations from the German are those of the author.

${ }^{10}$ Wales, the Isle of Man, Devon and Cornwall. In all of these, ogham represent the Irish language while ogham-inscribed stones found in Scotland mostly contain inscriptions in the Pictish language.

${ }^{11}$ However, it is impossible to say whether the erection of a stone and its inscription are contemporary or whether stones erected much earlier where simply incised during this period. Such re-use of monumental stones was common practice in Celtic-speaking (and Scandinavian) areas and may have occurred for practical or symbolic reasons or through cultural shifts (Busset, 2007: 35).

${ }^{12}$ The attested re-use of the stones for instance as building materials at times makes it impossible to localize their position at erection, but this is not an issue of concern for the present argument.

${ }^{13}$ Elva Johnston (2013: 13) proposes that the notches and dots may have been viewed as symbolic forms rather than as written words, favouring a symbolic role of the script over a communicative function.

${ }^{14}$ See, for example, McManus (1997), Anthony Harvey (1987), James Carney (1975), FC Diack (1931), Christian Graves (1876). See McManus (1997) for a full bibliography.

${ }^{15}$ The first is extant in In Lebor Ogaim ('The Book of Ogham'), an undated text written in Old Irish (the language of the $7^{\text {th }}-9^{\text {th }}$ centuries). It claims that ogham was invented by Ogma mac Elathan of the Túatha Dé Danann, the mythical (divine) race inhabiting Ireland before the human settlers arrived. The second, Auraicept na $n E$ Ees ('The Scholars' Primer'), is dated to the $7^{\text {th }}$ or $8^{\text {th }}$ century and concerned primarily with grammatical issues. It narrates that the Gaelic language (goidelc) and its script (ogham) were created by the scholar Fénius Farsaid, who selected the best of every language after the linguistic dispersal the tower of Nimrod, identified with the Tower of Babel (Genesis 11:1-9). See McManus (1997: 147-152).

${ }^{16}$ The term ancestor is used here in a broad context, i.e. not as definable progenitors but as the mass of forbearers from whom the medieval Irish thought themselves to descend, or who had shaped the landscape they inhabited with their presence (i.e. Túatha Dé Danann, see footnote 14). The term focuses 
less on genealogical lineages (although many genealogies do mention characters familiar from the sagas) but on the evocation of a common origin, a common cultural identity rooted in the past. Many similar yet uninscribed stone pillars are also extant in the Irish landscape and mentioned in literary texts as gravemarkers, yet the use of the ogham cipher adds an additional cultural dimension.

${ }^{17}$ Most are located in counties Cork, Kerry, and Waterford.

${ }^{18}$ These early, patronymic inscriptions are generally termed orthodox ogham.

${ }^{19}$ The script was used very sporadically in manuscripts from the $8^{\text {th }}$ century onwards, and from this use later reverted back to stone monuments, often with more varied inscriptions (referred to as scholastic ogham). These are not discussed in this article as they do not appear in the sagas or in poetry.

${ }^{20}$ Swift (2002: 127) points out that c. 20 (out of c. 360 stones) begin with the word anm ('name'), perhaps an analogy with the ainm n-oguim mentioned in the sagas.

${ }^{21}$ Busset examines carved stone monuments across Ulster (Northern Ireland), Scotland and Scandinavia. She concludes (2017: 33) that only a few can be associated with individual bodies although many are clearly in commemoration of individuals. Such non-correlations may therefore occur more widely.

${ }^{22}$ To my current knowledge, there is only one saga reference to a woman buried underneath an ogham stone (Tochmarc Ferbe). This might reflect the exclusively male names on the archaeological stones.

23 'Sense of place' is a concept employed in cultural geography and related fields and denotes the complex processes - religious, mythological, historical, political, ideological - through which groups (and individuals) define themselves in their relationship with 'their' landscape.

${ }^{24}$ Damian McManus (2016), personal correspondence.

${ }^{25}$ I thank Katherine Forsyth for pointing this out to me in her comments on an earlier draft.

${ }^{26}$ Frequently, this is narrated in a highly formulaic way in which the person's ainm n-ogum ('a funerary inscription consisting of the name of the deceased', McManus, 1997: 154) is inscribed on the stone.

${ }^{27}$ Such short expositions betray the desire of the medieval Irish to create an intricate knot-work in which place-names, historical documents and secular and ecclesiastical texts map the past and form a densely woven cultural memory. Rolf Baumgarten (1986/1987: 2) argues that in their desire to etymologize, the Irish became more Isidorian than Isidor himself, not content to accept the latter's caveat that some names simply could not be etymologized. As such, the medieval Irish literati felt they inhabited a world where everything could (should!) be explained with reference to their cultural memory.

${ }_{28}$ Cétchumnech, las cetna dernta chumni i n-ogmaib ar tus in hErinn (sic). The $14^{\text {th }}$-century Book of Ballymote also contains the genealogy and the addendum that the king was the fist-remembered, but no reference specifically to ogham stones. Discussed in John Mac Neill (1915: 85). See also R. I. Best et. al. (1967: 1379).

${ }^{29}$ The text is fragmentary and, although dated to the early $13^{\text {th }}$ century, is extant in manuscript witnesses from the mid- $15^{\text {th }}$ to the $16^{\text {th }}$ century.

${ }^{30}$ Translated by Dooley and Roe (1999: 97). Ocus ro cuired issin fert iarsin iat, \& ro tócbad a lía, \& ro scribad a n-ainm oghaim. Edited by Stokes (1900: 137). There are two other mentions of ogham as burial markers in the text as edited by Stokes.

${ }^{31}$ I thank Simon Taylor for reminding me of this metaphor in relation to toponyms.

${ }^{32}$ Francesco Benozzo (2004) attempts to outline 'how the structures of physical space can affect the narrative structures' (and vice versa) for medieval Irish and Welsh literature.

${ }^{33}$ Cladar a fert íarom. Sátir a lia. Scríbthair a ainm n-ogaim. Agair a gubae. See O’Rahilly (1976: 43 (ed.) \& 163 (trans.).

${ }^{34}$ British Library, MS Egerton 1782 (1516-1518), ff 30va-34 va and Dublin TCD Ms 1384 (H 5.12), 1749, f. $6 \mathrm{ff}$. It is a later version of Echtrae Fergus Maic Léite ('The Adventure of Fergus mac Léite', dated to the $8^{\text {th }}$ century on linguistic grounds but preserved in two legal manuscripts from the $16^{\text {th }}$ century, TCD H. 3.18 and Harley 432). Neither of the linguistically remarkably conservative manuscript witnesses of the older Echtrae Fergus Maic Léite features a burial ritual or a reference to ogham.

${ }^{35}$ Is do claided a fert ocus do scríbad a ainm ogham cus dorigned a chluiche cáintech ocus ró na hulltaib cloch dorónsat Ulaid agá cháined gairter Ulltaig díob. O’Grady (1892: 252 (ed.) \& 285 (trans.).

${ }^{36}$ The Dindshenchas are usually seen as a mnemonic index of stories linked to toponymy, but often the toponyms and their purported origin refer to features in they lived-in landscape, such as monuments. For a detailed evaluation of their mnemonic value and previous scholarship on the subject see Davies (2013). 
${ }^{37}$ The date is suggested by Best and Bergin (1938) on linguistic grounds.

${ }^{38}$ The text has a complex and fragmented transmission history. It is attested first in the $12^{\text {th }}$ century

(Lebor na hUidre) but is included 'in the ancient classified lists of prime stories' (Best and Bergin, 1938: 137), which enumerate the stories a learned poet (file) should have memorised. The list provides an idea of the 'prime tales' of medieval Ireland.

39 'class (?) a fert fodbuigh lat, ocus togabar a coirthe ocus a liagan, ocus scribtar a anmuimm oghaimm' Edited by Windisch (1880: 122), translated by McManus (1997: 154). This version of the text is preserved in British Museum Egerton 1782 ( $16^{\text {th }}$ century).

${ }^{40}$ Windisch (1880) bases this edition on British Library MS Egerton 1782 and Lebor na hUidre (RIA MS

23 E 25). The burial scene appears in the longest version of the text, preserved in British Museum

Egerton $1782\left(16^{\text {th }}\right.$ century). However, the much shorter earlier version of Tochmarc Étaine (preserved in the $12^{\text {th }}$-century manuscript Lebor na hUidre) does not contain this scene and reference, as McManus (1997: 185) points out. TCD 1318 (The Yellow Book of Lecan, 14 ${ }^{\text {th }}$ century) and TCD MS 1337 also preserve versions of the tale, but from these the scene is also absent. NLI MS G4 (originally part of the Yellow Book of Lecan) does preserve a version which includes the scene, yet here the funeral rite consists of the digging of a grave, the making of lamentations (sic) and the slaying of cattle.

${ }^{41}$ Both possibilities would need to be addressed in a larger study including all manuscript witnesses.

${ }^{42}$ Oidhe Chloinne Tuireann: The Death of the Children of Tuireann, ed. by Richard O'Duffy (1888: 1).

The tale is preserved most completely in a manuscript dated to 1820 . O'Duffy edited the text mainly from an obscure manuscript he calls C. C. M. R. I. A., which contains the story almost complete and is dated by the scribe, William Casey of Tralee, to May $3^{\text {rd }}, 1820$. Other manuscripts containing the tale are RIA 23 G. 10 and RIA 23 E. 16 , dated to the $19^{\text {th }}$ and $20^{\text {th }}$ century respectively. RIA 23 M. 47 preserves the story incompletely. Another copy is now known to exist (Edinburgh, NLS, MS 72.2.6., 18th century), although O'Duffy seems to have ben unaware of this.

${ }^{43}$ do cuiread Cian fá'n b-feart arís iar sin, agus do tógbad a lia ós a leacht, agus do fearad a cluite caointe, agus do sgriobad a ainm a n-ogam. Oidhe Choinne Tuireann. Edition and translation by O’Duffy (1888: 21 (ed.) and 89 (trans.)).

${ }^{44}$ Laoi Oisín ar Thir na $n O ́ g$, ed. by Brian Ó Luanaigh (1859: 4).

${ }^{45}$ This was recently contested by Briain Ó Dálaigh (2006/2007: 147-148). Whoever its author may have been, the poem is undoubtedly first attested in mid- $18^{\text {th }}$ century Co. Clare and is preserved in manuscripts from the mid- $19^{\text {th }}$ century onwards.

${ }^{46}$ 'Do chuireamair-ne an fear mór / i bhfeart fód-doimhin farsaing réidh; / do thógbhas a lia ós a leacht, / is scriobhas a ainm in ogham-chraobh.' Ó Luanaigh (1859: 41). Translation by Cross and Slover (1937: 447).

${ }^{47}$ For this see also Van Dyke (2008: 277-284), Holtorf and Williams (2006), Bradley (1993: 127-129).

${ }^{48}$ It would be interesting to extend such observations to the cultural nationalism in modern Ireland (see Leerssen 1986, 1996) and the role ancestral places played in it.

\section{Bibliography}

\section{Primary Sources and Manuscript Editions}

Acallam na Senórach (1999) trans. by Dooley A and Roe H. Oxford: Penguin Classics. Aidedh Ferghusa (1892) ed. by O'Grady SH in his, Silva Gadelica. A Collection of Tales in Irish. London: Williams and Norgate; 2 vols.

Ancient Irish Tales (1937) trans. by Cross TP and Slover CH. London: Barnes and Noble.

Auraicept na nÉces, The Scholars' Primer (1917) ed. and trans. by Calder G. Edinburgh: John Grant.

Irische Texte mit Wörterbuch (1900) ed. by Stokes W et al., 4 vols., vol 4.1. Leipzig: 
Hirzel, pp. 1-438.

Laoi Oisín ar Thír na nÓg (1859) ed. by Ó Luanaigh B. Dublin: Transactions of the Ossianic Society.

Oidhe Chloinne Tuireann: The Death of the Children of Tuireann (1888) ed. by O’Duffy R. Dublin: Gill.

Silva Gadelica: A Collection of Tales in Irish (1892) ed. and trans. by O'Grady SJ., 2 vols. London: Williams and Norgate.

The Book of Leinster (1954-1983) ed. by Best RI et. al. Dublin: Dublin Institute for Advanced Studies, vol. 5 (1967).

The HarperCollins Study Bible (2006) ed. by Meeks WA et al. California: HarperCollins Publishers.

\section{Secondary Sources}

Andrén A (1999) Landscape and Settlement as Utopian Places. In: Fabech C and

Ringtved J (eds) Settlements and Landscape. Hojbjerg: Jutland Archaeological

Society, pp. 383-393.

Andrén A (2013) The significance of places: The Christianization of Scandinavia from

a spatial point of View. World Archaeology 45: 27-45.

Assmann A (2011) Cultural memory and Western civilization: functions, media, archives. Cambridge: Cambridge University Press.

Baumgarten R (1986/1987) Placenames, etymology, and the structure of Fianaigecht. Béaloideas 54/55: 1-24.

Bergin O and Best RI (1938) Tochmarc Étaíne. Ériu 12: 137-196.

Benozzo F (2004) Landscape Perception in Early Celtic Literature. Aberystwyth: Celtic Studies Publications.

Bradley R (1993) Altering the Earth. The Origins of Monuments in Britain and Continental Europe. Edinburgh: The Rind Lectures.

Busset AM (2017) Early Medieval Carved Stones from Ireland, Scotland and Scandinavia: A Comparative Study Through Place, Movement, Memory and Identity. PhD thesis, University of Glasgow, UK.

Olschowsky B, Petransky I, Po'k A, Przewoznik A and Weber M (eds) (2011) Erinnerungsorte in Ostmitteleuropa: Erfahrungen der Vergangenheit und Perspektiven (= Schriften des Bundesinstituts für Kultur und Geschichte der Deutschen im östlichen Europa, vol 42. München: Oldenbourg.

Carney J (1975) The invention of the Ogom cipher. Ériu 26: 53-65.

Charles-Edwards T (1998) The context and uses of literacy in early Christian Ireland. In: Pryce H (ed) Literacy in medieval Celtic societies. Cambridge: Cambridge University Press, pp. 62-82.

Chedgzoy, K, Graham E, Hodgkin K and Wray R (2018) Preface. Memory Studies 11/1, $3-4$.

Connon A (2014) The Roscommon locus of Acallam na senórach and some thoughts as to tempus and persona. In: Doyle A and Murray K (eds) In Dialogue with the Agallamh: Essays in Honour of Seán Ó Coileáin. Dublin: Four Courts Press, pp. 21-59. 
Conway B (2010) Commemoration and Bloody Sunday: Pathways of Memory. London: Palgrave Macmillan.

Cooney G (2000) Landscapes of Neolithic Ireland. London \& New York: Routledge.

Cosgrove D (1984) Social formation and symbolic landscape. Wisconsin \& London: The University of Wisconsin Press.

Davies MT (2013) Dindshenchas, Memory and Invention. In: Hambro C and Widerøe L (eds) Lochlann: Festkrift Til Jan Erik Rekdal på 60-årsdagen = aistí in ómós do Jan Erik Rekdal ar a 60ú lá breithe. Oslo: Hermes, pp. 86-104.

Den Boer P, Duchhardt H, Kreis G and Schmale W (2012) Europäische Erinnerungsorte. 3 vols. München: Oldenbourg.

Diack FC (1931) The origin of the Ogam alphabet. Scottish Gaelic Studies 3: 86-91.

Erll A (2011) Memory in culture. Basingstoke: Palgrave Macmillan.

Fentress J and Wickham C (1992) Social Memory. Oxford: Basil Blackwell.

Françoise É and Schulze H (eds) (2005) Deutsche Erinnerungsorte. München: C.H. Beck.

Frawley O (2005) Irish Pastoral: Nostalgia and Twentieth-Century Irish Literature. Dublin \& Portland, OR: Irish Academic Press.

Glauser J (2014) Foreword. In: Hermann P, Mitchell S and Arnórsdóttir A (eds) Minni and Muninn: Memory in Medieval Nordic Culture. Turnhout: Brepols, pp. vii-x.

Glauser J (2007) The speaking bodies of saga texts. In: Quinn J, Heslop K and Wills T (eds) Learning and understanding in the Old Norse world. Essays in honour of Margaret Clunies Ross. Turnhout: Brepols, pp. 13-27.

Glauser J (2000) Sagas of the Icelanders (Íslendinga sögur) and pættir as the literary representations of a new social space. In: Clunies Ross M (ed) Old Icelandic literature and society. Cambridge: Cambridge University Press, pp. 203-220.

Gosden C and Marshal Y (1999) The cultural biography of objects. World Archaeology 31/2: 169-178.

Graves C (1876) On the Ogam alphabet. Hermathena 2: 443-472.

Hackett C and Rolston B (2009) The burden of memory: Victims, story-telling, and resistance in Northern Ireland. Memory Studies 2(3): 355-76.

Hahn H, Traba R, Górny M and Konczal K (2008) Deutsch-polnische Erinnerungsorte /Polskoniemieckie miejsca pamiçi. Rahmenbedingungen des Projekts. Berlin: Ferdinand Schöningh.

Hall MA (2015) Lifeways in stone: memories and matter-reality in early medieval sculpture from Scotland. In: Williams H, Kirton J and Gondek M (eds) Early medieval stone monuments, materiality, biography, landscape. Woodbridge: The Boydell Press, pp. 182-215.

Harvey A (1987) Early literacy in Ireland: the evidence from Ogam. Cambrian Medieval Celtic Studies 14: 1-15.

Harvey D and Jones R (1999) Custom and habit(us): the meaning of traditions and legends in early medieval western Britain. Geografiska Annaler. Series B, Human Geography 81(4): 223-233.

Herbert M (2007) Crossing historical and literary boundaries: Irish written culture around the year 1000. Cambrian Medieval Celtic Studies 53/54: 87-101. 
Herbert M (1988) The world, the text and the critic of early Irish heroic narrative. Text and Context 3: 1-9.

Hermann P, Mitchell S and Arnórsdóttir A (2014) Introduction: Minni and Muninn memory in medieval Nordic culture. In: Hermann P, Mitchell S and Arnórsdóttir A (eds) Minni \& Muninn: memory in medieval Nordic culture. Turnhout: Brepols, pp. 1-10.

Hermann P (2014) Key aspects of memory and remembering in Old Norse-Icelandic literature. In: Hermann P, Mitchell S and Arnórsdóttir A (eds) Minni \& Muninn: memory in medieval Nordic culture. Turnhout: Brepols, pp. 13-39.

Ho Tai HT (2001) Remembered Realms: Pierre Nora and French National Memory. The American Historical Review 106/3: 906-922.

Holtorf C and Williams H (2006) Landscapes and Memories. In: Hicks D and Beaudry MC (eds) The Cambridge Companion to Historical Archaeology. Cambridge: Cambridge University Press, pp. 235-254.

Johnston E (2013) Literacy and Identity in Early Medieval Ireland. Woodbridge: Boydell Press.

Jones A (2007) Memory and material culture. Cambridge: Cambridge University Press. Jones R and Fowler C (2008) Placing the nation: Aberystwyth and the reproduction of Welsh nationalism. Cardiff: Cardiff University Press, pp. 1-42.

Jones R (1999) Mann and men in a medieval state: the geographies of power in the Middle Ages. Transactions of the Institute of British Geographers 24(1): 65-78.

Jones S and Russell L (2012) Archaeology, memory and oral tradition: an introduction. International Journal of Historical Archaeology 16(2): 267-283.

Jones S (2011) Sorting stones: monuments, memory and resistance in the Scottish highlands. In: Beaudry M and Symonds J (eds) Interpreting the early modern world: transatlantic perspectives. Boston, MA: Springer, pp. 113-139.

Kreis G (2010) Schweizer Erinnerungsorte. Aus dem Speicher der Swissness. Zürich: Verlag Neue Zürcher Zeitung.

Kritzman LD (1996) In Remembrance of Things French. In: Kritzman LD (ed) Realms of Memory: Rethinking the French Past, Vol 1: Conflict and Divisions. New York: Columbia University Press, pp. ix-xv.

Leerssen J (1996) Remembrance and imagination: patterns in the historical and literary representation of Ireland in the nineteenth century. Cork: Cork University Press.

Leerssen J (1986) Mere Irish \& fior-ghael: Studies in the idea of Irish nationality, its development and literary expression prior to the nineteenth century. Cork: Cork University Press.

Legg S (2007) Reviewing geographies of memory/forgetting. Environment and Planning A 39: 456-466.

Legg S (2005) Contesting and surviving memory: space, nation, and nostalgia in Les Lieux de mémoire. Environment and Planning D: Society and Space 23: 481504.

Leigh Fry S (1999) Burial in medieval Ireland, 900-1500: A review of the written sources. Dublin: Four Courts Press. 
Lethbridge E (2016) The Icelandic sagas and saga landscapes: writing, reading and retelling Íslendingasögur narratives. Gripla XXVII: 51-92.

MacGugan JH (2012) Landscape and lamentation: Constructing Commemorated Space in three Middle Irish texts. Proceedings of the Royal Irish Academy: Archaeology, Culture, History, Literature, 112C: 189-217.

Mac Neill J (1915) On the reconstruction and date of the laud synchronism. Zeitschrift für Celtische Philologie 10: 81-96.

Mallory JP (1992) The world of Cú Chulainn: the archaeology of Táin Bó Cúailnge. In: Mallory JP (ed) Aspects of the Táin. Belfast: December Publications, pp. 103159.

Marchal GP (2003) Erinnerungsorte. In: Blatter M and Schilling S (eds) Erinnerungsorte? Ein Test. Wie sich Einwohner Luzerns erinnern. Zürich: Chronos Verlag, pp. 92-104.

McAreavey N (2018) Building bridges? Remembering the 1641 rebellion in Northern Ireland. Memory Studies 11/1: 100-114.

McCone K (1990) Pagan past and Christian present in early Irish literature. Maynooth: An Sagart.

McManus D (1997 (1991)) A guide to Ogam. Maynooth: An Sagart.

Moore F (2010) The Ogham stones of county Kerry. In: Murray G (ed) Medieval treasures of county Kerry. Tralee: Kerry County Museum, pp. 6-18.

Moore F (1998) Munster Ogham stones: siting, context and function. In: Monk MA and Sheehan J (eds) Early medieval Munster: archaeology, history and society. Cork: Cork University Press, pp. 23-32.

Ní Ghrádaigh J (2015) A stone in time: saving lost medieval memories of Irish stone monuments. In: Williams H, Kirton J and Gondek M (eds) Early medieval stone monuments, materiality, biography, landscape. Woodbridge: The Boydell Press, pp. 216-240.

Nora P (2001) Rethinking France: Les Lieux de Mémoire, Vol 1: The State, trans. by Mary Trouille. Chicago: University of Chicago Press.

Nora P (1989) Between memory and history: Les Lieux de memoire. Representations 26: 7-24.

Nora P (1996) From Lieux de mémoire to Realms of Memory. Preface to the English Language Edition. In Kritzman LD (ed) Realms of Memory: Rethinking the French Past, Vol 1: Conflict and Divisions. New York: Columbia University Press, pp. xv-xxiv.

O'Sullivan A, McCormick F, Kerr TR and Harney L (2014) Early Medieval Ireland, AD 400-1100. The evidence from archaeological excavations. Dublin: Royal Irish Academy.

Ó Corráin D (1978) Nationality and kingship in pre-Norman Ireland. In: Moody TW (ed) Nationality and the pursuit of national independence. Belfast: The Appletree Press, pp. 1-35.

Ó Dálaigh B (2006/2007) Micheál Ó Coimín: Jacobite, protestant and Gaelic poet, 1676-1760. Studia Hibernica 34: 123-150.

Ó hUiginn R (1992) The Background and Development of Táin Bó Cúailnge. In: 
Mallory JP (ed) Aspects of the Táin. Belfast: December Publications, pp. 29-67. Petts D (2003) Memories in stone: changing strategies and contexts of remembrance in early medieval Wales. In Williams H (ed) Archaeologies of remembrance: death and memory in past societies. New York: Springer, pp. 193-214.

Pine E (2010) The Politics of Irish Memory: Performing Remembrance in Contemporary Irish Culture. Basingstoke: Palgrave MacMillan.

Poppe E and Rekdal JE (eds) (2014), Medieval Irish perspectives on cultural memory. Münster: Nodus Publications.

Poppe E (2014) Narrative history and cultural memory in medieval Ireland. In: Rekdal JE and Poppe E (eds) Medieval Irish perspectives on cultural memory. Münster: Nodus Publications, pp. 135-176.

Rekdal JE (2014) Memorials and cultural memory in Irish tradition. In: Rekdal JE and Poppe E (eds) Medieval Irish perspectives on cultural memory. Münster: Nodus Publications, pp. 109-133.

Rolston B (2010) Trying to reach the future through the past: Murals and memory in Northern Ireland. Crime, Media, Culture: An International Journal 6/3, 285307.

Schade G (2011) Griechische Erinnerungsorte und Erinnerungsräume. Hermes 139/1: $112-119$.

Schama S (1996) Landscape and Memory. New York: Vintage Books.

Schlüter D (2014a) Medieval Manuscripts and Cultural Memory. The case of the Book of Leinster. In: Rekdal JE and Poppe E (eds) Medieval Irish perspectives on cultural memory. Münster: Nodus Publications, pp. 61-79.

Schlüter D (2014b) Update on some trends and fashions in cultural memory studies. In: Rekdal JE and Poppe E (eds) Medieval Irish perspectives on cultural memory. Münster: Nodus Publications, pp. 13-14.

Schlüter D (2010a) History or Fable? The Book of Leinster as a document of cultural memory in twelfth-century Ireland. Münster: Nodus Publications.

Schlüter D (2010b) For the entertainment of lords and commons of later times. Past and Remembrance in Acallam na Senórach. Celtica 26: 146-160.

Schneidmüller B (2006) Erinnerungsorte aus dem europäischen Mittelalter. Ruperto Carola 3: 4-10.

Sheeran P (1988) Genius Fabulae: The Irish Sense of Place. Irish University Review 18/2: 191-206.

Sjoestedt ML (1949) Gods and Heroes of the Celts. London: Methuen.

Stein-Hölkeskamp E and Stein-Hölkeskamp KJ (2010) Erinnerungsorte der Antike. Die griechische Welt. München: C.H. Beck.

Stein-Hölkeskamp E and Stein-Hölkeskamp KJ (2006) Erinnerungsorte der Antike. Die römische Welt. München: C.H. Beck.

Swift C (1997) Ogam stones and the earliest Irish Christians. Maynooth: An Sagart.

Swift C (2002) Ogam Stones in Sligo and their Context. In: Timoney MA (ed) $A$ Celebration of Sligo: First essays for Sligo Field Club. Sligo: Sligo Field Club, pp. 127-140.

Thomas C (1971) The early Christian archaeology of north Britain: the Hunter 
Marshall Lectures. Oxford: Oxford University Press.

Tristram H (2009) Narratology and Salvation: Aspects of 'Narrated Time' and the 'Time of Narrating' in Táin Bó Cúailnge. In: Ó hUiginn R and Ó Catháin B (eds) Ulidia 2. Proceedings of the Second International Conference on the Ulster Cycle of Tales. Maynooth: An Sagart, pp. 31-45.

Tymoczko M (2014) The Nature of Tradition and Cultural Memory. In: Rekdal JE and Poppe E (eds) Medieval Irish perspectives on cultural memory. Münster: Nodus Publications, pp. 15-60.

Van Dyke RM (2008) Memory, Place, and the Memorialization of Landscape. In: David B and Thomas I (eds) Handbook of Landscape Archaeology. Walnut Creek: Left Coast Press, pp. 277-284.

Williams H (2006) Death and memory in early medieval Britain. Cambridge: Cambridge Studies in Archaeology.

Williams H, Kirton J and Gondek M (2015) Introduction: Stones in Substance, Space and Time. In: Williams H, Kirton J and Gondek M (eds) Early medieval stone monuments: materiality, biography, landscape. Woodbridge: Boydell Press, pp. $1-34$.

\section{Author's biography}

Sarah Künzler received her $\mathrm{PhD}$ from the University of Zurich in 2015. She subsequently held a Swiss National Science Foundation Early Post-Doc Mobility fellowship (2016-2017) and is currently a British Academy Post-Doctoral Fellow at Celtic and Gaelic, University of Glasgow. She is working on a monograph discussing mnemonic aspects of landscapes and places in early Irish texts. 